This is an electronic reprint of the original article. This reprint may differ from the original in pagination and typographic detail.

Author(s): Hämeenaho, Pilvi

Title: $\quad$ Tieto, valta ja vastuu erityislasten hoidossa

Year: $\quad 2016$

Version:

Please cite the original version:

Hämeenaho, P. (2016). Tieto, valta ja vastuu erityislasten hoidossa. Elore, 23(2). https://doi.org/10.30666/elore.79256

All material supplied via JYX is protected by copyright and other intellectual property rights, and duplication or sale of all or part of any of the repository collections is not permitted, except that material may be duplicated by you for your research use or educational purposes in electronic or print form. You must obtain permission for any other use. Electronic or print copies may not be offered, whether for sale or otherwise to anyone who is not an authorised user. 


\title{
TIETO, VALTA JA VASTUU ERITYISLASTEN HOIDOSSA
}

\author{
Pilvi Hämeenaho
}

/ Kyllä vanhemmat on lapsensa tarpeiden parhaita tunnistajia", Anna $(\mathrm{H} 2)^{1}$

totesi minulle, kun puhuimme hänen kokemuksistaan erityistä tukea tarvitsevien lastensa hoitojen suunnittelusta. Hän oli ärtynyt, koska oli juuri ennen haastatteluamme käynyt epämiellyttävän puhelinkeskustelun hoitoalan ammattilaisen kanssa. Puhelun aikana Anna oli kokenut tulleensa vähätellyksi ja jopa loukatuksi. Hänen näkemyksiään lapsensa hoidon tarpeesta ei ollut kuunneltu, ja kyseinen ammattilainen oli ilmoittanut oman kantansa Annan mukaan kielteiseen, jopa halveksuvaan sävyyn.

Annan mielipide vanhempien kuulemisen ja heidän näkemyksiinsä uskomisen tärkeydestä lasta koskevissa asioissa ei ole vain hänen omansa. Tämän artikkelin aineistona käyttämäni kokemuskertomukset ${ }^{2}$ osoittavat, kuinka monet erityistä tukea tarvitsevien lasten (jatkossa erityislapset ${ }^{3}$ ) vanhemmat jakavat Annan mielipiteen. Taustalla on kokemus siitä, että vanhempien tietoja ja heidän lapseensa liittyvää asiantuntemusta ei haluta huomioida hoitoa suunniteltaessa ja siitä päätettäessä. Tutkimukseni lähtökohtana onkin huomio vanhempien alisteisesta asemasta terveydenhuollon järjestelmissä. Palvelun hakijan ja sitä tarjoavan ammattilaisen välinen vallan epäsymmetrisyys perustuu toimijoiden erilaisiin rooleihin ja on osittain luonnollista. (Pohjola 2006, 44.) Väärinkäytettynä tämä valta-asetelma saattaa kuitenkin johtaa vuorovaikutuksen ongelmiin, negatiiviisiin palvelukokemuksiin ja pahimmillaan jopa hoidon viivästymiseen ja epäonnistumiseen.

Tässä artikkelissa tarkastelen vanhempien asemaa palvelujärjestelmän sisällä palvelutilanteita ohjaavien kulttuuristen kategorioiden (ks. Jokinen 2012) ja niihin kiinnittyvien, käytännön toimintaan vaikuttavien merkitysten ja arvoasetelmien kautta. Tutkimuksessani olen analysoinut erityislasten vanhempien tietoa ja asiantuntijuutta suhteessa asiakkaan kategoriaan sisäänkirjoitettuihin oletuksiin ja määritelmiin. Anneli Pohjola $(2006,44)$ on tiivistänyt auttamistyön työntekijöiden ja asiakkaiden kategoriset määritelmät käsitteellisiksi vastapareiksi. Työntekijä on

$1 \quad$ Haastateltavien nimet muutettu.

2 Kertomukset, joita tämän artikkelin aineistona käytetään, on julkaistu kirjassa Leijonaemojen tarinat - Kasvu erityislapsen vanhemmaksi sekä kerätty haastatteluina Koulua ja elämää varten -tutkimushankkeessa.

3 Termin erityislapset käyttöä kritisoidaan sen kokonaisvaltaisuuden vuoksi. Termi määrittelee lapsen ainoastaan "erityisyytensä" kautta ja häivyttää siten hänen yksilöllisyytensä ja muut ominaisuutensa (leimaavista määrittelyistä, ks. esim. Itäpuisto 2005). Käytän termiä kuitenkin tässä tutkimuksessa ensisijaisesti siksi, että myös erityislasten vanhempien vertaistukijärjestö, Leijonaemot, on käyttänyt sitä julkaisussaan Leijonaemojen tarinat. 
Pilvi Hämeenaho: Tieto, valta ja vastuu erityislasten hoidossa

[http://www.elore.fi/arkisto/2_16/hameenaho.pdf]

auttaja ja asiantuntija, asiakas puolestaan autettava, tavallinen inminen, jonka roolina on ottaa vastaa tietäjän tarjoamaa tietoa (myös healer-patient -kategoriat, Frank ym. 2010). On huomionarvoista, että nämä kategoriat koskevat myös tietoa. Epäsymmetrisissä valtasuhteissa auttamistyön toimijoiden erilaisille tietoperustoille rakentuva ymmärrys ei asemoidu ainoastaan erilaiseksi, vaan myös eriarvoiseksi suhteessa yhteistyön tavoitteisiin (ks. Popay \& Williams 1996; Pohjola 2006; Koskinen 2014).

Geoffrey Bowker ja Susan Leigh Star (2000) ovat todenneet kategorioiden olevan osa inhimillistä tapaa jäsentää maailmaa ja luokitella ilmiöitä ja asioita. Ihmisiä eri tavoin luokittelevat kategoriat voivat olla sekä oman ryhmän identiteetin rakennusta että ulkopuolelta annettuja, stereotypioihin ja ulkopuoliseen katseeseen perustuvia. Kategoriat ovat itsessään kulttuurisesti rakentuvia ja kuvastavat paikkaan ja aikaan sitoutuvia käsityksiä normaalista ja poikkeavasta sekä yleisestä ja erityisestä. Stereotypisoivat kategoriat ovat korostuneen yksinkertaistettuja, ja ne pyrkivät lokeroimaan yksilöt vain yhden muuttujan perusteella. Tällaisia muuttujia voivat olla esimerkiksi sukupuoli, maahanmuuttajuus tai vaikkapa tietyn alan ammattilaisuus. (Esim. Suopajärvi 2009, 30-31; Juhila 2012, 184; Buchert 2015.)

Kuten Pohjolan määrittelemät käsiteparit osoittavat, asiakkaiden ja ammattilaisten kategorioiden mukaiset roolit asettuvat toistensa vastakohdiksi. Donileen Losaken $(2007,173)$ mukaan ammattilaisten valta-asema hoitotilanteissa oikeutetaan professionaalisuuden määritelmän avulla. Erityisterveydenhuollon ammattilaisten osaaminen ja tiedot perustuvat biolääketieteelliselle tietoperustalle, jolla on itsestään selvä valta-asema esimerkiksi lääkäreiden ja potilaiden kohtaamisissa (myös Fischer 2008, 587; Farrer ym. 2015). Asiakkaiden tieto puolestaan määritellään kokemustiedoksi, joka perustuu yksittäisille ja henkilökohtaisille kokemuksille, eikä vastaa kokonaisvaltaisen ymmärryksen tai lääketieteellisen tiedon tarpeeseen (ks. Prior 2003, 53; Frank ym. 2010, 35). Esimerkiksi vanhempien käsitys lapsen oireista tai sairauksista mielletään sirpaleisena ja vain yksittäistapauksia koskevana, eikä sille hoitoneuvotteluissa voida antaa asemaa oikeana, toisin sanoen lääketieteellisesti validina, tietona. Tällöin tilanteessa, jossa lapsen oireita pyritään diagnosoimaan lääketieteellisesti, asiakas on maallikon roolissa ja hänen tietonsa alisteista suhteessa lääkärin ammattilaistietoon.

Kuten kulttuuriset kategoriat, myös tiedon hierarkkista arvottamista ohjaavat institutionaaliset kategoriat muuttuvat ajan, paikan ja toimijoiden mukaan (Bowker \& Star 2000, 291; Buchert 2015, 39). Onkin muistettava, että myös lääketieteellinen tieto perustuu ideologisille arvoasetelmille, jotka ovat sekä neuvoteltavissa että myös muutettavissa esimerkiksi uuden tutkimuksen myötä (Lock 2001, 483; Fischer 2008, 584; Honkasalo 2008a, 13; Goldstein 2013). Myöskään asiantuntijuutta ja kykyä osallistua hoitojen suunnitteluun ei tule määritellä vain ammatillisen kyvykkyyden kautta, vaan on huomioitava asiantuntijuuden eri ulottuvuudet (Alasuutari 2010). Niin sanotun faktatiedon lisäksi asiantuntijatieto rakentuu myös asian henkilökohtaisesta tuntemisesta ja siihen liittyvästä osaamisesta eli taidoista. Kuten Collins ja Evans (2007, 2-3) esittävät, asiantuntijuus tulee määritellä tietyn ryhmän jäsenten todellisen osaamisen ja heidän tietojensa kautta. Esimerkiksi sairaan tai vammaisen henkilön ja hänen hoitajansa asiantuntemus rakentuu tiedoille 
ja taidoille, jotka kertyvät elämänkulun ja tiedonkeruun myötä, ja jotka mahdollistavat vamman tuottamien haasteiden kanssa selviämisen. (Myös Kangas 2003, 77; Toom 2008, 38-39).

Näin katsottuna ammattilais- ja maallikkotiedon välinen ero ei näyttäydy niin suurena kuin (lääke)tieteellisen tiedon arvoa korostavat näkemykset antavat ymmärtää. Auttamistyön tilanteissa inhimillinen vuorovaikutus on keskeinen tapa rakentaa monialaista tietoa, jossa yhdistyvät asiakkaan kokemukset ja ammattilaisen tieto (esim. Mertala 2001, 98-99). Sen sijaan, että korostetaan esimerkiksi biolääketieteellisen tiedon ja asiakkaan oman tiedon välisiä eroja, erilaisia ihmiskäsityksiä tai oireiden ja vammojen merkityksellistämistä, tulisi ammattilais- ja maallikkotietoa tarkastella toisiaan täydentävinä tietoperustoina. Samalla nousee tarve tarkastella kriittisesti asiakkaita määrittelevien kategorioiden käyttökelpoisuutta tai riittävyyttä heidän todellisen toimijuutensa ja asiantuntijuuden jäsentäjinä.

Tässä artikkelissa rakennan kuvauksen siitä, millaista tietoa ja asiantuntijuutta erityislasten vanhemmilla on ja kuinka heidän tietoperustansa rakentuu. Lähtökohtanani on tiedon ymmärtäminen neuvottelunalaisena ja muuttuvana kulttuurisena konstruktiona. Tällöin tieto ymmärretään paikantuneena ja inhimillisen toiminnan ja vuorovaikutuksen kautta rakentuvana. (Haraway 1993; Bowker \& Star 2000 Koskinen 2014). Tietoa ja sen merkitystä tulee tarkastella suhteessa tiedon tarpeisiin - ei vain sen lähtökohtiin, kuten kiinnittymisestä tiettyyn tieteenalaan tai ammattiin. Erityislasten vanhempien asiantuntijuuden määrittelyssä on tärkeää myös huomioida sen perustana olevan tietoperustan monialaisuus. Vanhempien lastaan koskevan ymmärryksen määritteleminen vain kokemustiedoksi on harhaanjohtavaa. Käytännössä erityislasten vanhempien asiantuntijuus rakentuu laaja-alaisesti kattaen alleen arkikokemusten lisäksi myös runsaasti muuta, esimerkiksi tieteellistä tietoa. Onkin syytä pohtia, sopiiko maallikkotietoon usein liitetty sirpaleisuuden määritelmä kuvaamaan vanhempien tietoperustaa, vai kuvaako se itse asiassa paremmin tietyn aiheen, kuten sairauden, vamman tai tietyn hoitomuodon erityisosaajan tietoa?

Artikkelin lähtökohdat ovat emansipatorisia (esim. Pinder 2010, 715-716), ja kuvaan auttamistyön tilanteita ainoastaan erityislasten vanhempien näkökulmasta. Kuvaamalla vanhempien asiantuntemuksen rakentumista ja heidän tietoperustansa todellista laajuutta teen näkyväksi kokemustiedon merkityksen lasta koskevan kokonaisvaltaisen näkemyksen rakentamisessa. Asiakkaan kategorian purkamisella ja täydentämisellä en pyri ammattilaistiedon merkityksen kyseenalaistamiseen hoitoon liittyvän päätöksenteon tärkeimpänä perusteena. Tutkimuksellani haluan kuitenkin edistää sitä, että vanhempien kokemukset ja heidän näkökulmansa tulevat huomioiduksi osana auttamistyön vuorovaikutustilanteita ja niiden seurauksien tarkastelua (vaikuttamiseen pyrkivästä etnologisesta tutkimuksesta, esim. O 'Dell \& Willim 2016, 71-72).

Asiakaskokemuksen keräämisen ja asiakkaiden näkökulmien huomioimisen tarve on vahvasti tunnistettu sekä terveydenhuollon tutkimuksessa että palvelujen tarjoajien keskuudessa. Tämä näkyy esimerkiksi siinä, kuinka asiakkaille on annettu kokemusasiantuntijoiden rooli, jonka merkitystä pyritään kasvattamaan osana 
terveydenhuollon tutkimusta ja kehittämistä. Myös laadullisten tutkimusmenetelmien laajamittainen käyttö sairauden ja terveyden tutkimuksessa monipuolistaa yhteistä tietoperustaa ja tuo mahdollisuuden asiakas- ja ihmislähtöiseen toimintaan. (Esim. Prior 2003; Williams \& Elliott 2010,107.) Tähän asiakaslähtöisyyttä ja kokemustiedon hyödyntämistä edistävään sosiaali- ja terveydenhuollon tutkimuksen kenttään myös oma tutkimukseni kiinnittyy.

\section{INSTITUTIONAALINEN VALTA JA TIETO}

Tutkimuksen keskiössä ovat hoitotyöhön liittyvät asiakkaiden ${ }^{4}$ ja ammattilaisten kohtaamiset. Hoitotyö tai auttamistyö, kuten esimerkiksi lääkärin, sairaanhoitajien tai terapeuttien työ, pyrkii inhimillisen hyvän lisäämiseen. Tavoitteena on sekä tunnistaa asiakkaan ongelmat ja tarpeet että tarjota niihin ratkaisuja. Auttamistyön tavoitteisiin pääseminen perustuukin hoitoa tarjoavan ammattilaisen ja asiakkaan yhteistyölle. Vuorovaikutukselle ja inhimilliselle kohtaamiselle perustuvan auttamistyön lähtökohtana on humanistinen ihmiskäsitys sekä luottamus ihmisen omaan toimijuuteen, hänen kykyynsä kehittyä ja muuttua. (Hurtig ja Laitinen 2006, 11; Frank ym. 2010, 34.)

Auttamistyön tilanteet ja toiminta ovat aina sidoksissa erilaisiin toimijoiden välisiin valtasuhteisiin (Pohjola 2006, 43; Hugman 2013, 84). Terveydenhuollon kentällä ammattilaisten ja asiakkaiden kohtaamisissa korostuvat institutionaaliset valtasuhteet, jotka määrittävät tilanteessa olevien toimijoiden roolit, heidän oikeutensa ja vastuunsa ja siten heidän toimijuutensa rajat (Honkasalo 2008a, 13; Buchert 2015, 41). Institutionaaliset valtasuhteet perustuvat niin sanotulle neuvotellulle järjestykselle (negotiated order, Strauss 1978), jossa eri toimijat kategorisoidaan kulttuurisesti rakentuvien määritelmien ja arvoasetelmien mukaan (myös Lock 2001, 479; Hugman 2013). Kuten Pohjola (2006) painottaa, lähtökohtaisesti erilaiset roolit eivät saisi auttamistyön arjessa muuttua arvoasetelmiksi. Kategorioihin helposti kiinnittyvä arvottaminen kuitenkin mahdollistaa toimijoiden välisten valtasuhteiden määrittymisen epäsymmetrisyyden lisäksi myös epätasa-arvoisesti (myös Frank ym. 2010).

Ulla Buchert $(2015,155)$ on todennut, että institutionaaliset kategoriat ovat usein negatiivisella tavalla leimaavia ja tuottavat auttamistyön kohtaamisiin toiseutta ja vastakkainasettelua yhteisymmärrykseen ja inhimilliseen tasa-arvoisuuteen pyrkimisen sijaan. Tällöin auttamistyön pahan säikeet (Hurtig \& Laitinen 2006; Pohjola 2006) ujuttautuvat mukaan palvelutilanteisiin ja voivat johtaa monenlaisiin vallan epätasa-arvoisesta jakautumisesta johtaviin ongelmiin. Pahan säikeet näkyvät tilanteissa, joissa ammattilainen käyttää valta-asemaansa siten, että asiakas kokee tulevansa vähätellyksi tai hänen tietonsa mitätöidään. Aineistojen analyysissä esiin nousevat kokemukset ammattilaisten välinpitämättömyydestä asiakkaan tunteita kohtaan tai hänen tietojensa ja näkökulmiensa mitätöiminen ovat Pohjolan (2006) määritelmän mukaisia pahan ilmenemismuotoja.

$4 \quad$ Vaikka hoitotyössä ammattilaisen vastaparina on usein potilas, käytän tässä tutkimuksessa termiä asiakas tai vanhempi. Tutkimukseni tarkastelee tilannetta jossa hoidon kohde eli potilas on alaikäinen ja hänen edustajanaan toimii hänen vanhempansa. Viittaan asiakkuudella siihen yleiseen rooliin, joka lastaan edustavalla vanhemmalla on suhteessa terveydenhuoltojärjestelmään. 
Pilvi Hämeenaho: Tieto, valta ja vastuu erityislasten hoidossa

[http://www.elore.fi/arkisto/2_16/hameenaho.pdf]

Epätasaisesti jakautuvan vallan perustana on asiakkaan - avun tarvitsijan - lähtökohtainen alisteisuus, joka on seurausta hänen heikentyneestä kyvystään huolehtia itsestään ilman ulkopuolista tukea ja apua (Nussbaum 2011, 20; Hugman 2013, 84). On tärkeää huomioida, kuinka yksilön haavoittuvuus suhteessa järjestelmään ja epätasa-arvoiset toimintamahdollisuudet sekä kyky puolustaa itseään ja oikeuksiaan syntyvät sekä yksilöllisistä että myös järjestelmän tuottamista toiminnan rajoitteista. Kun tutkimuksen kohteena ovat erityistä tukea tarvitsevat henkilöt, joiden toimintakyky on alentunut joko psyykkisten ongelmien tai esimerkiksi vammaisuuden vuoksi, on erityisen tärkeää huomioida kaikki haavoittuvuutta tuottavat tekijät. Erityistä tukea tarvitsevien henkilöiden toimintapotentiaali suhteessa esimerkiksi palvelujärjestelmään onkin rajoittunut sekä heidän sairauksiensa tai vammojensa vuoksi että järjestelmän taholta tulevien rajoitteiden kautta. Järjestelmä asettaa vammaiset ja heitä edustavat inmiset eriarvoiseen asemaan monin valtasuhteisiin liittyvin keinoin, jotka rajoittavat heidän toimintamahdollisuuksiaan. (Esim. Pohjola 2006; Frank ym. 2010; Perlin 2011.)

Sridhar Venkatapuram (2011) on todennut, että sosiaalinen epäoikeudenmukaisuus on keskeinen syy sekä terveysongelmille että yksilön mahdollisuuksille muuttaa omaa (terveydellistä) tilannettaan. Sen vaikutukset näkyvät sekä institutionaalisissa käytänteissä että niitä ohjaavien arvojen tasolla. Sosiaalista epäoikeudenmukaisuutta tuottavan järjestelmän perusteita onkin haettava kulttuurista. Sherry Ortnerin (1984) mukaan kulttuurisesti rakentuva merkitysjärjestelmä saa jatkuvasti vahvistusta inhimillisen toiminnan kautta, koska tätä toimintaa ohjaavat yhteisössä hyväksytyt arvoasetelmat. Vaikka arvolatautuneet kategoriat ovat neuvoteltuja ja siksi myös muutettavissa, tulee niistä käytännön toiminnan kautta normeja.

Michael Perlin (2011) on osoittanut, että erityisesti mielenterveysongelmat johtavat usein tilanteeseen, jossa henkilön yhteiskunnalliset oikeudet eivät toteudu. Hän näkee tämän olevan seurausta yhteiskunnallisista ja kulttuurisista asenteista, jotka saavat syrjinnän näyttämään oikeutetulta. Perlin toteaa näiden asenteiden olevan usein piiloisia ja niin sisäänkirjoitettuja esimerkiksi instituutioiden käytäntöihin, ettei niiden diskriminoivaa luonnetta tunnisteta (myös Pohjola 2006, 43). Perlinin tutkimat institutionaalisen syrjinnän keinot ja niiden käyttö ovat osa Ortnerin määrittelemää arjen toimintaa, jolla yksilöt - järjestelmän eri instituutioiden toimijoina - vahvistavat kulttuuriin sisäänkirjoitettuja valta-asetelmia. Kategoriat tuleekin nähdä toimintaa ohjaavina ja tuottavina vallankäytön välineinä sen sijaan, että niihin suhtaudutaan pysyvinä ja kiistämättöminä auttamistyön roolituksina (Jokinen 2012, 262; Buchert 2015). Kategorioiden piiloisuus johtaa kuitenkin siihen, että niiden lähtökohtia tai ideologisia perusteita ei välttämättä enää huomata eikä osata kyseenalaistaa arjen toimien tasolla (Bowker \& Star 2000, 290-291; Honkasalo 2008a, 13; Buchert 2015, 42). Näkymätön valta on vaikeasti tunnistettavissa ja sen tuottamiin epäkohtiin on hankalaa puuttua.

Institutionaalisten valtasuhteiden tuottamat kategoriat ja tiedon hierarkiat heikentävät myös mahdollisuutta tunnistaa asiakkaiden asiantuntijuus ja sen laajuus. Tämä voi johtaa yhteistyön sijaan tietoperustojen yhteentörmäyksiin ja tarpeeseen tehdä valintoja erilaisten tietojen välillä. Kuten tutkimukset (ks. Popay \& Williams 1996; 
Pilvi Hämeenaho: Tieto, valta ja vastuu erityislasten hoidossa

[http://www.elore.fi/arkisto/2_16/hameenaho.pdf]

Haraway 1993; Lock 2001, 483) osoittavat, biolääketieteen totuudet tai sen inmistä oireiden ja sairauksien kautta hahmottava ihmiskäsitys eivät useinkaan sovi yhteen asiakkaiden kokemusten kautta kertyneen, kokonaisvaltaisen ja ihmisen yksilönä tunnistavan tiedon kanssa. Hoitotilanteessa vastakkaisiksi asettuvat ammattilaisja asiakastieto ovat hierarkkisesti eriarvoisia ja lääketieteellinen tieto mielletään normiksi, jonka mukaan toimitaan.

Erityislasten vanhempien kokemukset (esim. Leijonaemojen tarinat 2015, 29, 88, 127) osoittavat, että heidän tietonsa ja ymmärryksensä aiheesta jätetään joskus jopa kokonaan huomiotta, kun lasta koskevia ratkaisuja tehdään. Artikkelini aineiston rajaus vanhempien kokemuksiin nostaa esiin heidän näkökulmansa, jonka ohittaminen on palvelutilanteisiin liittyvien negatiivisten kokemusten keskeinen peruste. Anneli Pohjolan mainitsemat auttamistyön käytäntöihin kietoutuvat pahan säikeet ovat helposti tunnistettavissa erityistä tukea tarvitsevien lasten vanhempien kokemuskerronnassa. Olen tarkastellut epätasa-arvoiseen kohteluun liittyviä kokemuksia sekä analysoinut niiden syitä ja seurauksia suhteessa erilaisia tietoperustoja ja asiakkaan roolia määritteleviin kategorioihin ja niiden sisältämiin, toimintaa ohjaaviin arvoasetelmiin. Tutkimuksellani pyrin, Stuart Hallin (1992) ajatusta mukaillen, kuvaamaan tietyssä kulttuurisessa kontekstissa rakentuvien institutionaalisten käytänteiden ja kategorioiden voimaa ja merkitystä toimintaamme ja ajatteluamme ohjaavina vallankäytön välineinä (myös Miller \& Rose 2010, 289). Samalla rakennan kuvan siitä, millaista tietoa erityislasten vanhemmille kertyy, ja millaista asiantuntijuutta tämä monialainen tieto heille tuottaa.

\section{Aineistot}

Tämä tutkimus perustuu kahdelle aineistokokonaisuudelle: tutkimushaastatteluille, jotka olen toteuttanut osana Koulua ja elämää varten -tutkimushanketta ${ }^{5}$ sekä erityislasten vanhempien kokemuskirjoituksille. Tässä artikkelissa käytän tutkimusta varten keräämästäni haastatteluaineistosta neljän erityislapsen vanhemman roolissa tutkimukseen osallistuneen naisen haastatteluja. Haastattelujen keskeiset teemat käsittelivät lasten hoitopolkuja ja koulunkäynnin tukea, vanhempien kokemuksia yhteistyöstä moniammatillisen verkoston kanssa sekä erityislapsen vanhemmuuteen kasvua. Kolmella naisista oli tutkimushankkeeni kokonaisuuden kannalta katsottuna kaksoisrooli: yhdellä heistä oli varhaiskasvattajan koulutus ja runsaasti alan työkokemusta ja kaksi muuta olivat aktiivisesti mukana vertaisjärjestöjen toiminnassa. Tämä tuli esiin esimerkiksi siinä, että he pohtivat vuorovaikutuksen haasteita myös henkilökunnan näkökulmasta sekä saattoi vaikuttaa myös heidän halukkuuteensa osallistua tutkimukseen. Vaikka analysoinkin heidän haastattelujaan ensisijaisesti vanhempien näkökulmaa esiin tuovina aineistoina, edustavat he samalla myös muita hankkeessani tutkimia ryhmiä: ammattilaisia ja järjestötoimijoita. Terveyden ja hyvinvoinnin ylläpitämiseen liittyvien roolien sekoittuminen on nähtävä luonnollisena osana yksilöiden arkielämän toimijuutta (Hämeenaho 2014, 184). Samalla moninaisten arjen roolien läsnäolo tutkimusaineistossa vahvistaa artikkelissa esittämääni tarvetta asiakkuutta ja ammattilaisuutta

$5 \quad$ Koulua ja elämää varten - Kulttuuristen käytäntöjen merkitykset kodin, koulun ja psykiatrisen hoidon ammattilaisten yhteistyössä on Suomen Akatemian rahoittama kolmevuotinen etnologinen tutkimushanke. 
Pilvi Hämeenaho: Tieto, valta ja vastuu erityislasten hoidossa

[http://www.elore.fi/arkisto/2_16/hameenaho.pdf]

määrittelevien stereotypisoivien kategorioiden purkamiselle sekä eri toimijoiden erilaisten tietoperustojen uudelleen määrittelylle.

Toinen käyttämäni aineisto muodostuu seitsemästä erityislapsen vanhemman kirjoittamasta kertomuksesta. Jokainen kertomus rakentuu erilaisista temaattisista elementeistä kirjoittajan valintojen mukaan. Osa kertomuksista rakentuu kokonaisvaltaiseksi kuvaukseksi erityislapsen vanhemmuudesta, kun taas toiset keskittyvät tiettyihin, lapsen elämänkulun ja hoitohistorian kannalta kriittisiin vaiheisiin. Tarkastelen näitä tarinoita henkilökohtaisiin elämänkokemuksiin perustuvina kokemuskertomuksina (Riessmann 1993), jotka ensisijaisesti kuvaavat erityislapsen vanhemmaksi kasvamista, mutta joissa rakentuu myös kuva monialaisen asiantuntijuuden rakentumisesta.

Kokemuskertomuksissaan vanhemmat kuvaavat toistuvasti vanhempien ja hoitotyön ammattilaisten kohtaamisia sekä niitä erilaisia valtasuhteita, joita erityislasten hyvinvoinnista vastaavien toimijoiden välillä on. Useimmat kirjassa julkaistut kertomukset nostavat esiin yhteistyössä koettuja vaikeuksia ja puutteita hoitotapahtumiin liittyvissä inhimillisissä kohtaamisissa. Leijonaemojen tarinat sisältääkin runsaasti kuvauksia epäonnistumisista auttamistyön kentällä. Tämä ei tarkoita, että äitien näkemys hoitoalan ammattilaisista olisi vain negatiivinen. Painotus johtuu kirjan pyrkimyksestä nostaa esiin vanhempien ja ammattilaisten kohtaamisiin liittyviä epäkohtia, jotta niistä voidaan oppia ja löytää niihin ratkaisuja. (Lonka 2015, $11,13$.$) Kokemuskirjoittaminen palvelee usein tarvetta saada ilmaista tunteita ja$ jakaa kokemuksia aiheista, joista on vaikeaa puhua. Terveyteen ja sairauteen liittyvät aiheet sisältävät paljon elementtejä, jotka tekevät niistä puhumisen vaikeaksi. Toisaalta tarve saada kertoa ja jakaa kokemuksia ja tunteita on suuri, mikä näkyy esimerkiksi halukkuutena osallistua henkilökohtaisiin aiheisiin tarttuviin keruukyselyihin. (Paal 2011, 158; Honkasalo 2008b.) Myös Leijonaemojen tarinat on syntynyt kirjoittajien halusta kertoa oma tarinansa ja siten tuoda esiin lääketieteen ohjaamassa keskustelussa usein syrjään jäävä näkökulmansa.

Luin Leijonaemojen tarinat vasta tehtyäni haastattelut ja lukiessani saatoin todeta haastateltavieni puhuneen minulle hyvin samankaltaisista asioista ja nostaneen esiin sekä vastaavia tapahtumia että tunteita kirjaan kirjoittaneiden vanhempien kanssa. Onkin todettava, että Leijonaemot-järjestö, johon vuonna 2015 kuului yli 1500 jäsentä, oli tuttu kaikille haastateltavilleni. He myös aktiivisesti seurasivat sen toimintaa esimerkiksi hyödyntämällä sen tarjoamia vertaistukipalveluja tai kirjoittamalla itse järjestön blogiin. Haastateltavani kertoivat järjestön löytymisen olleen heille "kaiken muuttanut" tapahtuma, ja sen kautta saadun vertaistuen olleen ehdottoman tärkeää heidän oman jaksamisensa ja hyvinvointinsa kannalta.

Jo yli kymmenen vuotta toimineen järjestön vertaistukitoiminnalla on ollut merkittävä vaikutus erityislasten vanhempien selviämiseen arjen haasteidensa kanssa. Samalla sen voidaan nähdä myös antaneen mallin siitä, kuinka vaikeista kokemuksista voi ja on tärkeää puhua. Olen tulkinnut haastatteluaineistojen sekä Leijonaemojen tarinoiden sisällöllisen yhteneväisyyden olevan seurausta samankaltaisista kokemuksista, mutta näen sen liittyvän ainakin osittain järjestön myötä syntyneen voimaannuttavan sisäryhmäidentiteetin omaksumiseen. Aineistona 
käyttämäni julkaistut kertomukset ovat tärkeä osa toimintaa, jolla leijonaemo-identiteettiä on rakennettu ja ylläpidetty.

Olen analysoinut haastattelu- ja kokemuskirjoitusaineistot temaattisen sisällönanalyysin avulla. Teemat olen valinnut aineistolähtöisesti siten, että olen kiinnittänyt huomiota siihen, miten haastateltavat tai kirjoittajat ovat itse jäsentäneet kohtaamiaan ongelmia, ja kuinka he perustelevat omaa epäluottamustaan tai avun saamiseen ja saamattomuuteen liittyviä pettymyksen tunteitaan. Haastattelut etenivät esittämieni kysymysten pohjalta, ja olen käyttänyt niissä esiin nousevia teemoja lähtökohtana jaottelulle, jonka mukaan artikkelini teemat valitsin. Nämä teemat ovat erityislapsen vanhemmaksi kasvu ja erityisesti tarvittavan tiedon kerryttäminen, asiantuntijuuteen kasvu sekä kohtaamiset ammattilaisten kanssa. Kirjoitetuissa kokemuskertomuksissa kirjoittajat ovat jo tehneet valintoja siitä, mitä he haluavat nostaa esiin ja kuinka he yhdistävät yksittäisiä tapahtumia osaksi laajempaa, palvelujen toimivuutta ja siihen liittyvää vuorovaikutusta koskevaa kuvausta (myös Laurén 2010, 426). Näistä teksteistä hain sekä uusia näkökulmia että täydennystä haastattelujen kautta syntyneelle käsitykselleni siitä, miten vanhempien asiantuntemus rakentuu, ja millaisia merkityksiä vanhempien tietojen arvon tunnustamiselle tai niiden huomiotta jättämiselle annetaan.

Aineistoni tarjoaa syvälle menevän mutta kapean kuvan auttamistyön kohtaamisiin liittyvistä valta-asetelmista ja niiden taustalla vaikuttavista ammattilaisuutta ja asiakkuutta määrittelevistä kategorioista. Kysymyksenasetteluni ja tarkasteluni rajoittuvat yksinomaan vanhempien näkemyksiin, joita olen analysoinut heidän kertomustensa kautta. Artikkelini ei siis vastaa kysymykseen siitä, miten ammattilaiset kokevat samat tilanteet tai kuinka he ammattilaisina suhtautuvat vanhempien tietoihin ja asiantuntemukseen. Myös auttamistyön kohtaamisiin liittyvien tilanteiden moniulotteisuus, jota olisi voinut analysoida esimerkiksi havainnoimalla vanhempien ja ammattilaisten kohtaamisia, jää haastatteluille ja kokemuskerronnalle perustuvan tutkimuksen ulkopuolelle (menetelmästä myös Tuomaala 2008, 49).

Kerronta on aina jälkikäteistä, ja tapahtumahetkellä vaikuttaneet tunteet tai hetkeen sidotut, tilannetta muokanneet tapahtumat eivät ole sellaisenaan tavoitettavissa kerronnan kautta. Kokemuskertomusten kirjoittaminen, samoin kuin haastattelutilanne, edellyttävät kokemusten ja näkemysten selostamista toiselle ymmärrettävässä muodossa. Tässä prosessissa kokemukset muuntuvat kertomuksiksi, joihin valikoituu vain osa todellisissa kohtaamisissa koetuissa tapahtumista ja tunteista. Jälkikäteinen pohdinta nostaa esiin myös uudenlaisia tulkintoja tapahtumista, jotka eivät liity pelkästään kyseisiin hetkiin vaan kiinnittyvät osaksi kertojan muuta ajattelua ja elämismaailmaa. (Riessmann 1993.) Kertomukset ovatkin aina yksilöiden kokemuksista ja heidän omista intentioistaan käsin rakentuvia. Niitä ei tule lukea totuudellisina kuvauksina hoitotapahtumista tai niihin liittyvistä neuvottelutilanteista, vaan niiden arvo on siinä, kuinka ne tuovat esiin kertojan ja kirjoittajan oman kokemuksen.

Keskeinen tavoite kokemuskerronnan käytölle tutkimusaineistona on Diane Goldsteinin (2000) esiin nostama huomio siitä, että niin sanottu maallikkotieto sekä vertaistieto ja -tuki ovat tärkeitä tiedonvälityksen kanavia ja syventävät aihetta 
koskevaa ymmärrystä. Ne siis tarjoavat uudenlaisia näkökulmia ja relevanttia tietoa myös niille, joiden toiminta perustuu lääketieteelliselle tietoperustalle ja ammattiosaamiselle (myös Lonka 2015, 11). Maallikkotieto edellyttää kuitenkin kertojan omasta näkökulmasta rakentuvia kertomuksia sekä niiden aineistolähtöistä analyysia. Jos esimerkiksi terveydenhuoltoa asiakkaiden näkökulmasta koskevia kertomuksia kerätään tai niitä luetaan vain sairauskertomuksina (illness-stories), ne asettuvat osaksi bio-lääketieteellistä diskurssia ja vahvistavat käsitystä sairauteen tai vammaan keskittyvän tietoperustan riittävyydestä. Tällöin menetetään kokemuskerronnan keskeisin anti terveydenhuollon tutkimukselle: kertomusten kyky avata tarkasteltava ilmiö, ei vain toisesta näkökulmasta, vaan myös lääketieteen kannalta katsottuna erilaisessa, ihmisen ja hänen tarpeensa kokonaisuutena huomioivassa kontekstissa. (Goldstein 2013; Kelly 2010, 309.)

Oma kokemus ja näkemys kuvatuista tilanteista ei estä kertojia pohtimasta tilannetta myös toisen osapuolen näkökulmasta. Sekä haastatellut että kirjoittajat nostavat usein kertomuksissaan esiin sen, että he ymmärtävät myös ammattilaisten asenteiden ja käytöksen perusteita eivätkä haluakaan väittää antavansa kaiken kattavaa kuvausta tapahtumista. Heidän kokemuskertomuksensa onkin tulkittava omakohtaisista kokemuksista nousevina puheenvuoroina, joiden esittämiseen heillä on oikeus, ja joista voimme oppia.

\section{VANHEMPIEN VASTUU JA MONIALAINEN ASIANTUNTIJUUS}

Erityislasten hoidon tarpeet rakentuvat aina yksilöllisiksi kokonaisuuksiksi sekä pysyvistä että tiettyyn tilanteeseen liittyvistä terveydellisistä ongelmista. Ne kattavat alleen niin fyysiset kuin psyykkisetkin vammat tai oireet, jotka usein myös vaikuttavat toisiinsa tavoilla, joita ei lääketieteellisen osaamisen perusteella aina pystytä ennakoimaan. Erityistarpeiden monipuolisuutta kuvastaa hyvin se, kuinka haastateltavani Meri (H4), käytyään läpi poikansa Kallen erityisen tuen ja hoidon tarpeita toivoi, että löytäisin haastateltavakseni myös sellaisia perheitä, joissa ongelmat eivät olisi "ihan näin monialaiset". Kallen erityisen tuen tarpeiden lisäksi perheen arkea olivatkin rasittaneet monet palvelujärjestelmän hajanaisuudesta johtuvat seikat, joiden vuoksi lapsen tuen tarpeisiin ei ollut pystytty puuttumaan varhaisen tuen ihanteiden mukaisesti. Merin ajatus siitä, että yleensä ongelmat ratkeavat helpommin, on kuitenkin aineiston perusteella katsottuna osittain väärä. Hoitoprosessien monimutkaisuuden ja lapsen tarpeiden keskinäisen eriaikaisuuden tuomat ongelmat ovat yhdistävä tekijä erityislasten perheiden arjessa - syyt vain vaihtelevat sekä lapsen oireiden ja tarpeiden että esimerkiksi asuinpaikkakunnan palvelutarjonnan mukaan (esim. Seppälä \& Veijola 2012, 16-17).

Erityiset hoidontarpeet ovat myös nopeasti muuttuvia: erityislasten terveydelliset ongelmat ja hoidon tarpeet vaihtelevat uusien oireiden ja diagnoosien myötä, mutta myös (alun perin) väärin tehtyjen diagnoosien johdosta, jolloin vaivaan ei löydy selitystä ja hoito voi tuottaa uusia ongelmia. Erityislasten hoidon ja kuntoutuksen suunnittelun ja toteutuksen lähtökohtana tulisikin aina olla mahdollisimman laaja ja kokonaisvaltainen käsitys juuri kyseisen lapsen tarpeista ja terveydentilasta nyt ja aiemmin. Tämä tuottaa suuria haasteita diagnosoinnille, jonka yhteydessä vaatimus ammattiosaamisesta ja vahvasta erityisasiantuntijuudesta liittyy oireiden 
ja sairauksien monimuotoisuuden ja harvinaisuuden tuottamaan määritelmien teon vaikeuteen. Näissä tilanteissa voidaan hyödyntää erilaisia tietoperustoja, eikä ammattilaisten tieto ole ainoa jonka varassa lapsen tilannetta tulee tarkastella. (Esim. Koivikko \& Sipari 2006, 36-37; Dew 2016.)

Erityisterveydenhuollon ammattilaisten tieto on usein syvällistä mutta kapea-alaista. Erityistä tukea tarvitsevien lasten diagnosointiin ja hoitoon liittyvät palvelutarpeet ovat puolestaan korostuneesti moniammatillista osaamista ja tietoa vaativia. Tämä edellyttää ammattilaisten yhteistyötä ja kykyä valikoida relevantti tieto päätösten ja toiminnan pohjaksi. Tähänkin yhteistyöhön vaikuttavat eri ammattiryhmien väliset valtasuhteet ja hierarkiat, joissa useimmiten korostuu lääkäreiden ja lääketieteellisen tiedon valta. (Pfeiffer \& Cundari 1999, 112; Mertala 2011, 84, 92-93.) Ammattilaisten välisen yhteistyön lisäksi lapsen tilanteen ja tarpeiden kokonaisvaltainen tuntemus edellyttää tietoa hänen arkielämänsä tarpeista ja käytännöistä. Pelkän lääketieteellisestä näkökulmasta rakentuvan tiedon sijaan lapsen tilanteesta tuleekin kerryttää ymmärrystä, jonka perustana on moniulotteinen käsitys terveyteen ja sairauteen liittyvistä erilaisista ja muuttuvista tekijöistä (Haraway 1993). Arjen tasolta saatavaa kokonaisvaltaista, lapsen ihmisenä ja yksilönä tunnistavaa tietoa on yleensä vain vanhemmilla. Jos heidän tietoperustansa arvoa ja merkitystä ei tunnusteta, on vaarana, että jotain tärkeää tietoa jää huomioimatta.

Kun tieto ymmärretään osana sosio-kulttuurista kokonaisuutta, tulee mahdolliseksi purkaa erilaisten tietoperustojen välisiä arvo-asetelmia ja nähdä niiden merkitys ja arvo osana kokonaisvaltaisen näkemyksen ja tiedon rakentumista. Erityislasten kohdalla tieto on korostuneen paikantunutta - se kiinnittyy tiettyyn lapseen tietyssä, nopeasti muuttuvassa elämäntilanteessa eikä yhdelläkään toimijalla ole kaikkia erilaisia tietoperustoja kattavaa kokonaisnäkemystä. Terveydenhuollon ammattilaisten syvällinen, mutta ala- tai oirekohtainen asiantuntemus voi johtaa lapsen mieltämiseen vain yksittäisten psyykkisten oireiden tai fyysistä toimintakykyä rajoittavien vammojen kautta. (Haraway 1993; Fischer 2008.) Monet asiantuntijat, kuten esimerkiksi lastenpsykiatrit, tapaavat asiakastaan harvoin, eikä tapaamisilla välttämättä välity paljoakaan tietoa esimerkiksi arjesta kotona tai koulussa. Vanhemmilla ei puolestaan useinkaan ole lääketieteellistä asiantuntemusta tai muuta koulutuksen ja työkokemuksen kautta saatavaa, esimerkiksi hoitokäytäntöihin liittyvää alakohtaista asiantuntemusta.

Vanhempien kokemuskertomukset kuitenkin osoittavat, kuinka monialaiseksi asiantuntijaksi on ryhdyttävä, jotta lapsen asioita pystyy hoitamaan. Erityislapsen vanhemmuus tuo mukanaan kokonaisvaltaisen vastuun, joka kattaa alleen asioita jotka yleensä mielletään ammattilaisille kuuluviksi. Monialaiseen tietoon liittyvän vastuunkannon merkityksen oppi vakavasti allergisen lapsen äiti Valpuri (Leijonaemojen tarinat 2015, 79-102), kuten hän kertomuksessaan kuvaa:

Olisin kovin mielelläni antanut kaiken mahdollisen vastuun lääkäreille. Näin kuitenkin, ettei kukaan heistä ehtinyt pysähtyä ajatuksella miettimään Matiaksen tapausta. Yleensähän sen ikäisillä pitäisi vauvana alkaneiden ruoka-aineallergioiden alkaa helpottaa. Matiaksella ne olivat kuitenkin vasta puhjenneet. Yksikin lääkäri myönsi pahoitellen, ettei heillä ole aikaa tutustua potilaspapereihin kunnolla ennen 
Pilvi Hämeenaho: Tieto, valta ja vastuu erityislasten hoidossa

[http://www.elore.fi/arkisto/2_16/hameenaho.pdf]

vastaanottoa. Tajusin, ettei kenelläkään muulla kuin minulla itselläni voinut olla kokonaiskuvaa tilanteesta. (Leijonaemojen tarinat 2015,88.)

Lapsen terveydentilaa ja palvelutarpeita kuvaavan kokonaiskäsityksen luominen ja sen ajan tasalla pitäminen onkin tehtävä, jonka vanhemmat kokevat usein jäävän yksinomaan heidän vastuulleen. Erityislasten kohdalla haasteita tuovat poikkeukselliset oireet sekä erilaisten sairauksien, vammojen ja oireiden yhdistelmät, joiden syitä tai vaikutusta toisiinsa ei tiedetä. Erityislasten kohdalla tieto, joka tulisi ymmärtää ja sisäistää, kattaa kaiken jokapäiväisistä hoito- ja kuntoutustoimenpiteistä oireiden seuraamiseen ja oikea-aikaisen avun hakemiseen sekä edellyttää diagnoosien perusteiden ymmärtämistä ja määrätyn hoidon toteutumisen valvontaa. Lapsesta huolehtiminen sekä vastuun määrä johtaa siihen, että erityislapsen vanhemman tiedon tarve on valtava.

Kirsi (H1) kuvasi ensimmäisten diagnoosien jälkeen alkanutta asiantuntijaksi kasvuaan toteamalla: "Että siis tää tilanne, mikä nyt on saavutettu, niin tätä on rakennettu vuosia. Ja mä oon ite käyny tätä koulua tässä koko ajan, että mä osaan hoitaa ja vaatia järjestää kaikki asiat. Aluksihan se oli ihan järkyttävä sekasorto." Hän kertoi vuosien aikana oppineensa huolehtimaan käytännön asioiden hoidosta ja kaiken mahdollisen informaation hallinnasta: "Mä oon luonu itelleni tällasen täydellisen järjestelmän. Mulla on tietty vuosikello Kaapon asioissa, mitä pitää tehä millonkin, ihan sama mikä hakemus tulee postista tai mikä hakemus lähtee meiltä." (Kirsi, H1.)

Arkisen, lapsen kuntoutukseen ja asioiden hoitamiseen liittyvän vastuun lisäksi erityislapsen vanhemmat joutuvat pitämään huolta siitä, että ammattilaisilla on käytössään kaikki tarvittava tieto ja huolehtimaan siitä, että lapsen erityistarpeet huomioidaan hoitotoimenpiteissä. Valpuri kuvaa tarinassaan kuinka vastuunkannon tärkeys, se, että hän tiesi lapsensa asiat mahdollisimman tarkkaan, nousi toistuvasti esiin lapsen hoitopolulla. "Joka lääkärikäynnillä sain aloittaa Matiaksen sairaushistorian kertomisen alusta." (Leijonaemojen tarinat 2015,89.)

Aina viesti ei kuitenkaan tunnu välittyvän siten kuin vanhempi toivoisi. Haastateltavani Riikka kertoi, kuinka erään syksyn kuluessa, perheen asioita hoitavien sosiaalityöntekijöiden vaihtuessa moneen kertaan, he olivat istuneet suosituksena olevan yhden verkostotapaamisen sijaan kymmenessä palaverissa. Hänen mukaansa kaikissa käytiin läpi samat asiat, ja turhaan.

Kun [uusi] sosiaalityöntekijä ei ymmärtänyt lapsen diagnooseja, vaikka me kuinka väännettiin ratakiskoa ja hammaslankaa, nii sitten hän halusi kasata verkostopalaverin, johon tulee somaattisen puolen lääkäri, joka selvittää, mikä tällä lapsella on, kun me olemme juuri kaksi tuntia sitä hänelle selvittäneet. Niin se pitää tulla lääkäriltä, koska vanhemmathan ei voi tietää. (Riikka, H3.)

Tässä tilanteessa monet myös kokevat, että pelkkä maallikkotieto ei riitä, vaan heidän on yritettävä oppia ymmärtämään myös lääketieteen kieltä pystyäkseen auttamaan lastaan sekä kommunikoimaan ammattilaisten kanssa. Vanhempien kasvava asiantuntijuus ja myös muun kuin pelkän kokemustiedon kertyminen vahvistaa heidän mahdollisuuttaan osallistua auttamistyön neuvotteluihin ja lasta koskevaan 
päätöksentekoon. Raisa (Leijonaemojen tarinat 2015, 127) kertoo, kuinka hän oli ottanut avuksi lapsen monipolvisen hoitohistorian kertomiseksi tavan kirjoittaa "aanelosia", tiiviitä kuvauksia, joissa hänen lapsensa keskeiset diagnoosit, lääkitykset ja kaikki hoidon kannalta keskeiset tiedot olivat yhdellä paperilla. Hän toteaa:

Pattitilanne [ammattilaisen kanssa] on lauennut asiallisella muistiolla tai selvityspyynnöllä. Kirjoitettu teksti ei selvitä vain omaa vaan myös toisen päätä. [...] Mielestäni olen kirjoittanut ainakin kaksi sellaista muistiota tai kyselyä, jotka ovat pelastaneet Arvon hengen, tai ainakin estäneet vammautumisia. (Leijonaemojen tarinat $2015,127$.

Raisan kuvaamien muistioiden kirjoittaminen edellyttää kykyä tiivistää tärkein ja olennaisin tieto ehkä jopa useiden mappien kokoisesta hoitohistoriasta yhdelle, helposti luettavissa olevalle sivulle. Tämä edellyttää syvällistä ymmärrystä sekä diagnooseista, hoidoista että jatkuvasti päivittyvää kokonaiskäsitystä lapsen terveydentilasta ja siihen liittyvistä ongelmista. Tämänkaltaisen asiantuntijuuden saavuttaminen edellyttää tiedon kerryttämistä myös arkisen kokemusmaailman ulkopuolelta.

Kokemuskertomusten mukaan vanhemmat hyödyntävät sekä internetiä, eri alojen kirjallisuutta että vertaistukea etsiessään lapsen hoidon kannalta välttämätöntä tietoa. Toisaalta tiedon keruuta voivat ohjata myös tunteet ja tarve löytää toivoa ylitsepääsemättömän vaikealta tuntuvien diagnoosien edessä. Johanna (Leijonaemojen tarinat 2015, 51-75) kuvaa omaa tietoperustansa kasvua seuraavasti:

Minulla oli valtava tiedonjano. Luin kaiken mahdollisen erilaisista kehitysviivästymistä ja vammaisuuksista, mitä internetistä ja kirjastosta vain löytyi. Poimin tietotulvasta kaiken positiivisen, miten tämän päivän kuntoutuksella tehdään inmeitä ja miten tärkeätä varhaiskuntoutus on. Hankin itselleni melkoisen tietouden neurologiasta sekä fysioterapiasta yhden talven aikana. Halusin ymmärtää, mitä me voimme tehdä Pinjan auttamiseksi. Halusin ymmärtää sitä salatiedettä, mitä neurologit meille puhuivat. (Leijonaemojen tarinat 2015, 62.)

Johanna kirjoittaa myös etsineensä lastaan "internetin ns. onnellisesti päättyneistä tarinoista: 'Ennusteesta huolimatta lapsemme on täysin normaali!'" (Leijonaemojen tarinat 2015,62 .) Kun tiedonkeruuta ohjaavat pelot ja huolet, voi oppimisprosessi kerryttää myös virheellistä tietoa, mikä lisää väärinymmärrysten ja kommunikoinnin ongelmia tulevissa palvelukohtaamisissa. Vanhempien erityislapsen kanssa elämisen arjessa rakentuva asiantuntijuus ei siis muodostu ammattilais-asiantuntijuuden kaltaiseksi eikä voi korvata sitä. Tämä ei tarkoita sitä, ettei vanhemmilla voisi olla hoidon suunnittelun kannalta tärkeää tietoa. Tälle tiedolle ei kuitenkaan ole luontevaa tai itsestään selvää paikkaa hoitoneuvotteluissa, kuten kokemuskertomukset osoittavat.

\section{Tietoperustojen YHTEENTÖRMÄYKSIÄ}

Kun vanhemmat oivaltavat, että heidän lapsensa kehitys ei etene niin sanotun normaalin kaavan mukaan, käynnistyy koko elämän mullistava muutoksen ja oppimisen prosessi. Lapsen ensimmäiset diagnoosit tuovat helpotusta epätietoisuuteen, 
mutta samalla ne tuovat mukanaan myös pakon hyväksyä lapsen erityisyys ja samalla oman elämän pysyvä muutos. Etenkin alkuvaiheessa uusi elämäntilanne huolineen ja velvoitteineen tuntuu pelottavalta ja kaoottiselta ja huolen määrä voi horjuttaa vanhemman omaa mielenterveyttä ja jaksamista. (Esim. H1; Leijonaemojen tarinat 2015, 24, 62, 167.)

Pidemmällä aikavälillä tarkasteltuna yksi keskeinen arkielämän muutos on se, että perhe päätyy tiiviiseen yhteistyöhön eri alojen ammattilaisten kanssa tutkimusten, selvitysten, hoitojen ja jatkuvan kuntoutuksen myötä. Kun puhuin haastateltavieni kanssa yhteistyöstä hoitoalan ammattilaisten kanssa, esiin nousi niin myönteisiä kuin kielteisiäkin kokemuksia. Yleisellä tasolla kaikki tapaamani erityislasten äidit halusivat korostaa sitä, kuinka kiitollisia ovat siitä, että saavat asua maassa, jossa vaikeitakin sairauksia ja vammoja hoidetaan asiakkaan varallisuuteen katsomatta. Kuten edellä esiin tuodut aineistositaatit osoittavat, erityislasten ja heidän vanhempiensa arki sisältää runsaasti myös toisenlaisia kokemuksia, ikäviä tapahtumia lapsen hoitohistorian varrelta, jotka ovat muuttaneet vanhempien ajattelua ja käytöstä. Seuraavassa tuon esiin, miten vanhemmat kertovat niistä kokemuksistaan, joissa ammattilaisen ja maallikon väliset valtasuhteet muuttuvat tietojen ja oikeuksien arvottamiseksi. Pohdin myös, miten tämä on vaikuttanut vanhempien toimintaan.

Esimerkiksi epävarmat diagnoosit, jotka ovat erityislapsilla hyvin yleisiä, voivat johtaa tilanteisiin, joissa vanhempien tieto omasta lapsestaan saattaa jäädä lääkärin ammattilaistiedolle alisteiseksi. Riikka kertoi, kuinka hänen 6-vuotiaalle pojalleen oli lukuisten tutkimusten myötä todettu epilepsia. Epilepsiaan myönnetyn lääkityksen aloittamisen jälkeen lapsen perhe havaitsi voimakkaita ja erittäin kielteisiä muutoksia lapsen käyttäytymisessä. Riikka kertoi minulle:

Sillon syksyllä [...] ihan naps, tuntu et yön aikana tän pojan käytös muuttu, ja hänestä tuli valtavan aggressiivinen ja aivan jotenkin, ku hän oli sellanen aurinko, yhtä aurinkoa vaan sillon ku asiat on hyvin. Nii ihan eri poika niinkun muutti yön aikana meille. (Riikka, H3.)

Hän kertoi myös tulkinneensa, että muutoksen takana oli kyseinen uusi lääkitys, mutta asian selvittäminen ei edennyt kuten hän olisi toivonut:

Ku neurologi ei uskonu sitä. [...] mä olin pari kertaa vihjassu, että voiko se olla, koska alkoi aika pian sen lääkkeen alottamisen jälkeen, että voisko se olla sivuvaikutus. Ja neurologi väitti kivenkovaan, että ei, ei siitä tuu aggressioita. [...] Mä laitoin sit Leijonaemoihin [internetin keskustelupalstalle] kyselyn, et onks kellään ollu tätä lääkettä, että mitä sivuvaikutuksia siitä on tullu. Ja jos mä nyt sanon, että kaheksan kymmenestä vastaajasta ilmotti aggressiot, niin en hirveesti valehtele. (Riikka, H3.)

Vertaistuesta saamiensa tietojen jälkeen Riikka oli vaatinut neurologilta, että lääkitys lopetetaan, mutta tämä ei ollut suostunut. Riikka päätyi itse lopettamaan lääkkeen käytön, minkä seurauksena "viikko sen jälkeen ku se lääke oli kokonaan loppu, niin meille muutti takaisin se vanha, ilonen poika, joka siellä oli ollu." (H3.) Kertomuksensa päätteeksi Riikka kertoi myös ottaneensa yhteyttä neurologian poliklinikalle 
ja jättäneensä lääkärille viestin, jossa toivoi, ettei neurologi enää "koskaan, ikinä, milloinkaan enää kyseenalaista sitä, että mitä äiti kokee. Että niin väärässä hän oli". (H3). Kertomuksen todellinen loppukohta saavutettiin kuitenkin vasta kaksi vuotta kuvattuja tapahtumia myöhemmin, kun uusissa tutkimuksissa kyseenalaistettiin koko epilepsia-diagnoosi. "Ja sit neurologi ei loppuviimein ollukaan varma, että oliko pojalla koko epilepsiaa koskaan ollutkaan". (Riikka, H3.)

Asiakkaat toivovat, että ammattilaiset kohtaisivat heidät kokonaisina inmisinä sen sijaan, että keskittyisivät vain sairauteen tai vammaan (Kangas 2003, 73). Kun erityislapsen vanhempi kokee, ettei ammattilainen huomioi kaikkia lapsen hyvinvoinnin kannalta olennaisia tietoja, hän voi alkaa epäillä ammattilaisia ja heidän työmoraaliaan tai -motivaatiotaan. Vaikka kategorisesti ammattilaistieto edustaa lapsen hoidon kannalta tärkeintä ja joskus ainoana tietona riittäväksi määriteltyä tietoa, saattaa se lastensa erityispiirteet ja yksilöllisen, monialaisen hoidon tarpeet tietävien vanhempien silmissä vaikuttaa yksioikoiselta ja tunneköyhältä. Ongelmana edellä kuvatun, vanhempien mielestä liian haitallisia sivuvaikutuksia tuoneen lääke-episodin kohdalla ei ollutkaan lääkärin alkuperäinen pyrkimys lääkitä epilepsiaa, vaan ongelmia toi äidin esiin tuomien havaintojen mitätöiminen lääkettä koskevien sivuvaikutuslistojen kustannuksella. Vaikka lääkärin on työssään vaikeaa ja jopa mahdotonta nojautua yksittäistapausta kuvaavaan ja vain yhden äidin havaintoihin perustuvaan kokemustietoon, vanhemman näkökulmasta lääkärin toiminta näytti lasta kohtaan sydämettömältä ja vaikutti haluttomuudelta auttaa lasta uusien ongelmien ilmetessä.

Pettymys siitä, että ei tule kuulluksi, nousee esiin myös Leijonaemojen tarinoissa. Sari (Leijonaemojen tarinat 2015, 17-47) koki, että hänen lapsensa oireiluun ei puututtu, koska niitä ei pidetty todellisina ilman syyn selittävää diagnoosia.

Reetta sai maitokorvikkeensa sekaan sokeria. Sillä yritettiin selvittää sokeriaineenvaihdunnan häiriöitä. Lapsemme elimistö ei käyttäytynyt, kuten sen tällaisessa aineenvaihduntasairaudessa kuuluisi tehdä. Reetan kunto heikkeni. Reetta sanoi: "Olo", ja vaipui lattialle. Hän sai näitä kohtauksia päivittäin: hikisyys, valkoisuus, velttous. Lääkärit olivat inmeissään. Sanottiin: "Reetalla ei testien perusteella ole sokeriaineenvaihduntasairautta". Koska näille "olo"-kohtauksille ei voitu antaa selitystä, oireisiin ei puututtu moneen viikkoon. Tuntui, että Reetan kohtauksia ei otettu tosissaan. Minua ei uskottu. Eikä liioin hoitajia, jotka kellon kanssa odottivat sokerinannon jälkeistä "olo"-kohtausta. (Leijonaemojen tarinat 2015, 27.)

Kuten Pohjola $(2006,42)$ toteaa, auttamistyön kohtaamisiin sisältyy koko inhimillisyyden kirjo. Vaikka tavoitteena olisi hyvän tuottaminen, liittyy kohtaamisiin myös tahatonta tai tarkoituksellisesti esiin tulevaa pahaa. Vanhemman kokemus siitä, ettei häntä uskota, ja etteivät ammattilaiset pyri lapsen parhaaseen, kertoo huonosta palvelusta: puutteista inhimillisessä kohtaamisessa ja vuorovaikutuksessa.

Vanhempien tietojen käyttö tai hyödyntäminen ammattilaistiedon rinnalla on kuitenkin monella tapaa haasteellista. Siinä missä lääkärien tiedot perustuvat ammattikunnan kesken jaettuun tietoon, yleisesti hyväksyttyihin tutkimuksiin sekä tietoon eri hoitomuotojen vaikutuksista yleisellä tasolla, vanhempien tietoperusta rakentuu aina yksilölliselle pohjalle (Prior 2003; Frank ym. 2010). Tämän 
huomioi myös Valpuri (Leijonaemojen tarinat 2015, 92) pohtiessaan vertaistuen merkitystä tiedon saannin kanavana: "Sainkin [keskustelupalstalta] paljon tärkeää tietoa allergioista. Toki tietty kriittisyys piti muistaa ylläpitää. Arjen asiantuntijoina vanhemmat tunsivat parhaiten aina oman tilanteensa, jota ei voinut rinnastaa suoraan muihin." On totta, että vanhemmilla olevan tiedon asettaminen rinnakkaiseksi lääketieteellisen tiedon kanssa ei ole ongelmatonta, eikä usein mahdollistakaan. Ammattilaistiedon käytön ytimessä on ammatillinen koulutus ja lääkärien ensisijainen tavoite on vastata lapsen psyykkisiin tai fyysisiin oireisiin parhaalla tunnetulla tavalla, joka kyseisen lapsen kohdalla (esimerkiksi muista lääkityksistä tai perussairauksista johtuen) on mahdollinen. Tällöin tutkittu ja virallisesti hyväksytty, esimerkiksi lääkkeitä koskeva tieto, on eettisesti kestävin ratkaisu ja antaa myös ennusteen parhaan mahdollisen tuloksen saavuttamisesta.

Vanhemman voi olla kuitenkin vaikeaa ymmärtää itselleen vieraita sairaalamaailman käytäntöjä tai sitä, millaiseen tietoon lääkärien toiminta perustuu. Ongelmia tuottavat myös kommunikaation esteet, esimerkiksi lääkärien puhuma "munkkilatina" - kuten Riikka viittasi ammattilaisjargoniin puhuessaan lääkärien ja vanhempien välisen yhteistyön ongelmista (H3; myös Lonka 2015). Vanhempien kokemuskertomukset osoittavatkin, kuinka viestin välittymisen ongelmat ja virhetulkinnat voivat käytännössä johtaa "väärällä" kielellä kerrotun tiedon mitätöintiin ja huomiotta jättämiseen. Näin vanhempi ja hänen omalle, lasta koskevalle asiantuntemukselle perustuva näkemyksensä voi jäädä huomiotta.

Kun vanhempaan suhtaudutaan ainoastaan maallikkona, joka auttamistyön kategorioissa määrittyy avun ja tiedon tuottajan sijaan niiden vastaanottajaksi, ei hänen tiedoilleen ole paikkaa hoidon suunnittelussa ja siitä päätettäessä. Tällainen tilanne tuo korostuneesti esiin myös asiakkaan kategoriaan liittyvät ongelmat. Kun valtasuhteiden eriarvoisuus ulotetaan koskemaan erilaisia tietoperustoja, voi osa lasta koskevasta tiedosta jäädä käyttämättä, koska se ei täytä ammattilaistiedon kriteeriä. Yksioikoinen ja asiakkaan monialaisen asiantuntijuuden huomiotta jättävä kategorisointi voikin johtaa siihen, että lapsen hoidossa ei huomioida olemassa olevaa, jopa elintärkeää tietoa siksi, että sen haltija ei ole "muodollisesi pätevä" tiedon omistaja.

\section{IRTIOTTOJA ASIAKKAAN ROOLISTA}

Tutkimukset osoittavat, että hyvään ja tasavertaiseen kohtaamiseen liittyvät arvot ja asenteet eivät aina näy käytännöissä (esim. Perlin 2011). Asiakaslähtöisen kehittämisen tavoitteet, toisin sanottuna asiakkaan kuuleminen ja hänen näkökulmansa ymmärtäminen ja huomioiminen osana auttamistyön neuvotteluja, edellyttääkin usein toimintakulttuurisia muutoksia hierarkkisten kategorioiden määrittämissä organisaatioissa. Vanhempien kertoman perusteella näyttää siltä, että neuvottelutilanteissa, joihin liittyy paljon hierarkkisuutta ja oletuksia eri osapuolten rooleista, ei ole käytettävissä selkeitä toimintamalleja. Näin ollen eri osapuolten voi olla vaikeaa hahmottaa, kuinka ja milloin asiakkaiden kokemustietoa voi hyödyntää osana ammattilaistiedolle perustuvia prosesseja. Lapselle parasta hoitoa ja kuntoutusta ei ole mahdollista suunnitella ilman riittävää ymmärrystä lapsen arkielämästä. Vaikka hoitoa koskevan päätöksenteon tulee perustua ammattilaisten tiedolle, myös 
Pilvi Hämeenaho: Tieto, valta ja vastuu erityislasten hoidossa

vanhemmilla oleva kokonaisvaltainen ymmärrys lapsen arjesta on tietoa, jota hoidon suunnittelun tueksi tarvitaan.

Kun asiakaslähtöisiä arvoja ei siirretä hoitotyön käytänteisiin, ylläpidetään samalla vanhempien hankaliksi ja epäoikeudenmukaisiksi kokemia hierarkioita. Kokemus siitä, että lapsi ei saa riittävää hoitoa vain sen vuoksi, ettei vanhempien tietoja oteta tosissaan, johtaa turhautumiseen ja epäluottamukseen ammattilaisia kohtaan. Vanhemman taakkana on jatkuva huoli omasta lapsesta ja oireista, joita ei saada kuriin. Tällöin tunnetta siitä, että kaikki eivät yritä parastaan lapsen hyväksi, on vaikea käsitellä. Kokemuskertomukset tuovat esiin, miten äidit vastasivat hankalina ja jopa sietämättöminä pidettyihin tilanteisiin puolustautumalla tai koittaen rikkoa asiakkuuden myötä syntyvää avun ja tiedon vastaanottajan roolia. On myös huomionarvoista, että Leijonaemot ry. on syntynyt juuri tarpeesta saada ja jakaa vertaistukea tilanteessa, jossa vanhemmat ovat kokeneet, ettei apua ollut muualta saatavilla. Ryhmän nimi kuvaa heidän tunteitaan siitä vastuun määrästä, jota he olivat joutuneet kantamaan saadakseen apua ja äänensä kuuluville. Sari (Leijonaemojen tarinat 2015,34 ) muistelee kasvuaan lapsensa puolustajana hajanaisen palveluverkon sisällä seuraavasti:

Kävimme näyttämässä ongelmaa hoitajalle, lääkärille, kirurgille. Ensin omassa keskussairaalassamme. Sitten auton nokka kohti $150 \mathrm{~km}$ päässä olevaa yliopistollista sairaalaa. Matkasimme kuin kiertolaiset apua etsien, lääkettä pyytäen, neuvoja anellen, ohjeita rukoillen. Lopulta apu löytyi, lääke saatiin, hätä loppui. Apu ihmiseltä inmiselle. Kunnes tuli uusi hätä. Taas sama kierto. Tätä riitti. Mitään ei saanut helpolla, kaikki oli vaadittava, jopa kerjättävä. Välillä oli karjuttava äitileijonan lailla. Nuo karjahdukset kuluttivat minua sisältä. Joka murahduksella oli silti tarkoituksensa, luulen. (Leijonaemojen tarinat 2015, 34.)

Kokemuskertomusten valossa näyttää siltä, että kasvaminen lapsensa puolustajaksi ei tapahdu ilman syytä, vaan kertomuksissa korostetaan pakkoa. Huonot kohtaamiset palvelujärjestelmän kanssa ja kokemus siitä, että lasta ei haluta auttaa parhaalla mahdollisella tavalla pakottavat vanhemmat rooliin, jossa heidän on itse ajettava lapsensa asiaa. Toisten, edes auttamistyön ammattilaisten avun varaan heittäytymistä ei nähdä mahdollisena.

Meri (H4) oli kohdannut lukuisia ongelmia etsiessään sopivaa ja riittävää hoitoa pojallensa. Hänen mukaansa vaikeudet johtuivat ensisijaisesti siitä, että kokonaisvastuuta hankalasta tilanteesta ei ollut kenelläkään, eivätkä eri toimijatahot (kuten koulu ja sosiaali- ja terveyspalvelut) ottaneet "lasta omakseen" vedoten silloin auki olleisiin toimijoiden välisiin sopimuksiin. Tämä johti tilanteeseen, jossa Meri yritti itse löytää jonkun tahon, joka voisi edes tehdä tarvittavia tutkimuksia tai tarjota käytännön apua hankalaan arkeen. "Mä soittelin vaikka kelle ja vaikka kuinka moneen paikkaan mutta meillä ei ollu oikeutta mennä minnekään" (H4). Merin mukaan vanhemman vastuu jopa lakisääteisten palveluiden saamisessa on todella merkittävä ja avun saaminen vaati häneltä itseltään valtavia voimavaroja. Kysyessäni selviämisestä lapsen oikeuksien puolustamiseen liittyvän vastuun kanssa hän totesi: 
Pilvi Hämeenaho: Tieto, valta ja vastuu erityislasten hoidossa

[http://www.elore.fi/arkisto/2_16/hameenaho.pdf]

Kyllä varmaan täytyy sillä tavalla olla aika peräänantamaton ja rohkee että ehottelee tuntemattomille tahoille että me tarvittas [apua], että voisko ja saisko sinne tulla. Ei mua ois kukaan mistään löytäny muuten, mä soittelin siinä ihan, monta kuukautta ensin. (Meri, H4.)

Merin tarina kuvaa sitä kokonaisvaltaista ja ajoittain liian raskaalta tuntuvaa vastuuta, joka vanhemmille kasaantuu erityislapsen asioiden hoitamisesta. Tämä vastuu kattaa alleen niin käytännön arjen tuen ja hoidon tarjoamisen lapselle, erilaisten taloudellisten tukien hakuprosessit kuin myös palvelujärjestelmän edustajien kanssa käytävät, epäsymmetrisille valtasuhteille perustuvat neuvottelutkin. Epäonnistuessaan nämä neuvottelut johtavat helposti huonoihin palvelukokemuksiin ja saavat vanhemmat puolustuskannalle. Esimerkiksi Riikka puhui ammattilaisten kanssa esiin tulevista kommunikoinnin ongelmista turhautuneeseen sävyyn. Hän totesi: "Vaikka sanotkin [ammattilaisille] kaiken, niin eihän ne kuule kun sen oman erikoisalansa." (H3.) Kun vanhempi kokee, että yritys välittää kokonaiskuvan kannalta olennaisen tärkeää tietoa epäonnistuu, tulee hänelle korostunut tarve saada oma äänensä kuulluksi.

Anna (H2) kertoi minulle haastattelun aikana törmäävänsä usein tilanteisiin, joissa joutuu "sanomaan aika tiukasti" tai "korottamaan ääntään" saadakseen asiansa kuuluville. Raisan kertomuksessa äänen korottaminen puolestaan toteutuu konkreettisesti, kun äiti huutaa lääkärille tuolilla seisten saadakseen tuotua huolensa ilmi ja ammattilaiset kuuntelemaan häntä (Leijonaemojen tarinat 2015, 129). Äitien tapa puolustautua ja vaatia on kuitenkin ymmärrettävä myös muunlaisena tilanottona kuin vain hetkeen sidottuina tunteenpurkauksina. Erityislasten moninaisten ja hankalasti yhteen sovitettavien ongelmien vuoksi vanhemmat kokevat joskus, että heidän on murtauduttava ulos autettavan asiakkaan kategorian tuottamasta maallikon roolista ja yritettävä toimia ammattilaisten kentällä. Näin siitä huolimatta, että heidän kokemus- tai maallikkotiedolle ei ole varattuna luontevaa paikkaa hoidon suunnittelussa, eikä valmista mallia, jonka mukaan toimia, ole.

Kategorian mukaisesta roolista poikkeaminen, kuten esimerkiksi vanhemman pyrkimys osallistua keskusteluun asiantuntijana, voi olla vaikeaa terveydenhuollon kentällä, jossa bio-lääketieteelliselle tiedolle ja osaajille on annettu valta-asema. Aiemmin käsitelty Riikan tarina toimii esimerkkinä tilanteesta, jossa vanhemman voidaan katoa ylittäneen roolinsa ja sen tuomien valtuuksien rajat päättäessään epilepsialääkityksen lopettamisesta vastoin lääkärin ohjetta.

Institutionaalisten, ammattilaisen ja asiakkaan välisten valta-asetelmien lisäksi myös muut epätasa-arvoiset kategoriat vaikuttavat palvelutilanteiden sosiaaliseen kanssakäymiseen. Esimerkiksi sukupuolten väliset arvottavat erot voivat nousta esiin tilanteissa, joissa vanhemman uskottavuutta puntaroidaan. Yksinhuoltajaäiti Raisa (Leijonaemojen tarinat 2015, 127) oli havainnoinut tiedon vaihtoon ja vanhempien kuulemiseen liittyviä käytäntöjä vietettyään pitkiä aikoja sairaaloissa lapsensa Arvon kanssa. Hänen kertomuksensa rakentuu useille kuvauksille siitä, miten vanhemman tietoja saatetaan vähätellä, mutta hän pohtii myös syitä ammattilaisten käytöksen takana: 
Pilvi Hämeenaho: Tieto, valta ja vastuu erityislasten hoidossa

[http://www.elore.fi/arkisto/2_16/hameenaho.pdf]

Olen omakohtaisesti nähnyt sairaalassa tilanteita, joissa lapsipotilaan isän sanaa on kuultu, vaikka äiti on aikaisemmin yrittänyt sanoa samaa. Arvolla ei ole käytössään toista eli isän suuta. En tiedä, tästäkö vai mistä johtuu, että minut on muutaman kerran ohitettu, kun Arvon hoidosta on päätetty. Olen hiukan yli puolitoistametrinen "Pikku Myy" ja inmetellyt, vaikuttaako sukupuoleni lisäksi vielä pieni kokoni siihen, että minua ei toisinaan tunnuta kuunneltavan. (Leijonaemojen tarinat 2015, 127.)

Roolien rikkomisen seurauksena yksilöt nousevat esiin asiakkaan kategorian takaa, ja auttamistyön luonne inhimilliselle kohtaamiselle perustuvana työnä korostuu. Konfliktitilanteissa kategorioiden taakse kätketyt valta-asetelmat ja rooliodotukset tulevat näkyviksi ja kyseenalaistetuiksi. Vanhempien kokemuskertomukset kuitenkin osoittavat, että välttämättä kummallakaan osapuolella ei ole välineitä käsitellä tällaista, totuttuja rajoja rikkovaa tilannetta. Asetelma, jossa ei tehdäkään yhteistyötä vaan ollaan selkeästi vastakkain, on vaikea niin asiakkaalle, joka kokee olevansa tilanteessa yksin ja puolustuskannalla kuin myös ammattilaiselle, jonka on kohdattava tunteidensa vallassa oleva asiakas-vanhempi kokonaisena ihmisenä (esim. H3). Joskus vanhemman tieto voi jäädä huomiotta esimerkiksi sen vuoksi, että hän ei tunteidensa vallassa pysty välittämään viestiään ammattimaisesti: asiaan keskittyen ja ilman tunteenpurkauksia. Joskus vanhemman voimakas puuttuminen asioiden kulkuun voi johtaa hänen tietojensa huomioimiseen, mutta asiallisen käytöksen ja hyvän vuorovaikutuksen kustannuksella. Raisa (Leijonaemojen tarinat, 105-141), jonka tarina sisältää värikkäitä kuvauksia huutamisesta ja riitelystä sairaalahenkilökunnan kanssa, toteaa omasta käytöksestään:

En aina jaksa huolesta ja väsymyksestä puolikuolleena välittää sairaalassa ns. käyttäytymisestä, jos on kyseessä Arvon kannalta kriittinen tilanne: naaraseläinkin muuttuu aggressiiviseksi, kun pentu on vaarassa. Se aggressio pelastaa pennun. Sama pätee ihmiseen. Minulla on hyvä omatunto. Pystyn mielestäni hyviin väleihin henkilökunnan kanssa. Pyydän käyttäytymistäni anteeksi toisinaan jo etukäteen. (Leijonaemojen tarinat 2015, 127.)

Riikka pohti haastattelun kuluessa ammattilaisten "tunteetonta" tai negatiiviselta vaikuttavaa suhtautumista: "Jotenkin joistain ammattilaisista paistaa semmonen, että he pelkää sen ammatti-identiteettinsä menettämisen puolesta jotenkin, et jos he eläytyykin siihen vanhempien hätään ja tuskaan." (H3.) Itsekin sairaanhoitajana hän kertoi, kuinka hänelle oli koulutuksen aikana korostettu ammatti-identiteetin säilyttämisen tärkeyttä ja omien tunteiden hillintää. Hän kuitenkin oli omalta osaltaan tullut siihen tulokseen, että empatian ja jopa tunteiden näyttäminen asiakkaille ei vähentänyt hänen kykyään toimia ammattimaisesti. Sen sijaan hän uskoi omien asiakkaan roolissa saamiensa kokemuksien perusteella, että inhimillisyys auttamistyön kohtaamisissa edistää sekä vaikeiden asioiden käsittelyä että niiden kanssa toimimista.

Riikan pohdinta nostaa esiin auttamistyön ammattilaisia ohjaavat roolit ja sen, kuinka ammattilaisroolin yksipuolinen korostaminen voi kätkeä ammattilaisen inhimillisyyden "lääkärintakin" alle (H3). Kategorioiden mukainen toiminta eli oman institutionaalisen roolin mukainen käytös voi toimia ammattilaisen omana selviytymiskeinona vaikeissa tilanteissa (myös Pohjola 2006, 47). Samalla se kuitenkin 
myös vahvistaa vallan epätasaiselle jakautumiselle perustuvaa asetelmaa auttamistyön kohtaamisissa ja tähän kiinnittyvien valta-suhteiden pysyvyyttä.

Vaikka roolien rikkominen voi tuottaa konflikteja, avaa se myös mahdollisuuksia tunnistaa piiloisia valta-asetelmia ja muuttaa niiden myötä syntyneitä käytänteitä. Jotta kertomuksissa kuvatut tilanteet asiakkaan kategorian vastaisesta käytöksestä eivät jäisi vain yksittäisiksi irtiotoiksi, olisi auttamistyön pahan säikeitä kyettävä ehkäisemään laajemmalla, toimintaympäristön kulttuuriseen muutokseen kannustavalla tavalla. Tässä tarve asiakkaan kategorian uudelleen määrittelylle tulee korostuneesti esiin. Avun vastaanottajan roolin sijaan vanhempien osallisuus lasta koskevissa neuvotteluissa tulisi olla heidän oikeutensa, jota kunnioitetaan ilman että he joutuvat sitä erikseen vaatimaan.

\section{Yhteenveto}

Olen artikkelissani kuvannut, kuinka erityislasten vanhemmat kertovat kohtaamisistaan ja asemastaan palvelujärjestelmän toimijoina. Olen analysoinut vanhempien kerronnassa esiin tulevia ongelmia, joita auttamistyön epäsymmetriseen vuorovaikutukseen ja asiakkaan asemaa ja toimijuutta kaventaviin kategorioihin liittyy. Erityisesti olen tarkastellut vanhempien tietoon ja heidän asiantuntijuuteensa liittyviä epätasa-arvoisia käytäntöjä ja niiden seurauksia vanhempien silmin katsottuna. Tutkimukseni tuo esiin, kuinka vanhemmat kokevat oman toimijuutensa ja lasta koskevan asiantuntemuksensa laaja-alaisemmaksi kuin järjestelmän muut toimijat sen näkevät. Samalla tutkimukseni osoittaa myös, kuinka asiakkuutta kapeasti määrittelevät kategoriat eivät kuvaa erityislasten vanhempien asiantuntemuksen todellista laajuutta tai monialaisuutta. Vanhempien asiantuntijuus on laaja-alaisempaa ja monipuolisempaa kuin asiakkaan kategoriaan sisäänkirjoitettu oletus heidän tiedostaan vain maallikkotietona tai ainoastaan omiin kokemuksiin rajautuneena tietona. Tutkimukseni nostaakin esiin tarpeen uusintaa asiakkaan kategoriaan sisäänkirjoitettuja käsityksiä asiakkaan toimijuudesta ja asiantuntemuksesta. Tutkimukseni osoittaa myös, kuinka tärkeää on pyrkiä erilaisten tietoperustojen tunnistamiseen ja yhteensovittamiseen, jotta toiminnan tavoitteena oleva lapsen paras voidaan saavuttaa.

Vanhempien kokemuskertomukset osoittavat, kuinka tarjolla olevien palvelujen sirpaleisuus ja eri alojen asiantuntijoiden keskittyminen vain oman erityisalansa mukaisiin lasta koskeviin seikkoihin johtaa vastuun kasautumiseen vanhemmille. Tämän seurauksena vanhemmilla on korostunut tarve kerryttää tietoa ja osaamista, joka siten usein muodostuukin paljon kokemustietoa laajemmaksi asiantuntijuudeksi. Mutta, kuten artikkelissani olen osoittanut, vanhempien kokemuksen mukaan heidän asiantuntemustaan ei aina tunnisteta, eivätkä vanhemmat koe, että heille aina annettaisiin tasa-arvoinen paikka auttamistyön neuvotteluissa. Asiakkaan rooli maallikkona myös asemoi hänen tietoperustansa vähempiarvoiseksi kuin hoitotyötä ohjaavan bio-lääketieteelliselle tiedolle perustuvan asiantuntemuksen.

Se, ettei vanhempien asiantuntemusta tunnisteta tai arvosteta, voi johtaa artikkelissani kuvaamiin tilanteisiin, joissa vanhemmat kokevat asemansa alisteiseksi auttamistyön neuvotteluissa ja lasta koskevassa päätöksenteossa. Heidän tietojensa 
Pilvi Hämeenaho: Tieto, valta ja vastuu erityislasten hoidossa

ohittaminen johtaa myös siihen, että vanhemmat tuntevat huolta siitä, saako heidän lapsensa parasta mahdollista hoitoa. Tämä heikentää vanhempien luottamusta ammattilaisia kohtaan ja voi vaikeuttaa muutenkin haastavaa yhteistyötä ja toimijoiden välistä vuorovaikutusta. Jos vanhemmat kokevat, että heidän mahdollisuutensa osallistua lasta koskevien asioiden suunnitteluun ei toteudu, he voivat alkaa puolustaa omaa asiaansa ja vaatia, että tulisivat kuulluksi.

Olen artikkelissani myös tarkastellut epätasa-arvoisiin valta-suhteisiin kiinnittyviä käsityksiä luotettavasta ja epäluotettavasta tiedosta sekä pohtinut sitä, miltä nämä käsitykset näyttävät suhteessa vanhempien omien kokemusten kautta kuvattuun asiantuntijuuteen. On totta, että tarvitsemme kategorioita ja luokitteluja saadaksemme välineitä ja käsitteitä, joiden avulla toimia. Nämä kategoriat eivät kuitenkaan saisi muuttua arvoasetelmiksi, joiden kautta auttamistyön luonnostaan epäsymmetrisesti jakautuvaa valtaa voidaan käyttää toisen toimijan alistamiseksi esimerkiksi syrjäyttämällä hänet tiedon keruun, jakamisen ja käyttämisen prosesseista. Kategorioiden tuottamia rooleja ja määritelmiä ei myöskään tule nähdä pysyvinä ja muuttumattomina vaan ymmärtää ne kulttuurisesti rakentuvina ja muuttuvina tapoina jäsentää moniulotteista todellisuutta. Tämä edellyttää kuitenkin tietoista pyrkimystä käytäntöjen muuttamiseen, koska samoin kuin tiedon hierarkiat myös toimijoiden välisen vallan epätasainen jakautuminen jää usein piiloon normeiksi muuttuneiden käsitysten ja niitä tukevan toiminnan taakse.

Valta-asetelmiin liittyvät näkymättömät oletukset tai normatiiviset käytännöt ohjaavat myös auttamistyön käytäntöihin punoutuvia pahan säikeitä. Paha ilmenee toisen vahingoittamisena sanojen, eleiden tai esimerkiksi toisen huomiotta jättämisen kautta. Kokemuskertomusten mukaan tällainen toiminta voi johtaa siihen, että toimijoiden välinen yhteistyö muuttuukin vastakkainasetteluksi, mikä vaikeuttaa kommunikaatiota ja yhteisymmärryksen muodostumista. Vastaavanlaiset ristiriitatilanteet eivät ole kenenkään toive, pyrkiihän auttamistyö lähtökohdiltaan aina hyvään yhteistyön inhimillisen vuorovaikutuksen kautta (Hurtig ja Laitinen 2006; Lonka 2015). Koska erityislasten hoidon kannalta tärkeää on kokonaiskuvan luominen, on kaikkien erilaisten tietojen huomiointi ja eri osapuolten välinen luottamus olennaisen tärkeää.

Toiminnan lähtökohtana tulee aina olla lapsen etu. Tällöin erilaisten tietojen merkitystä osana hoitojen suunnittelua tulisi arvioida sen perusteella, kuinka ne vastaavat käsillä oleviin ongelmiin sen sijaan, että ne arvotetaan tiedon haltijan statuksen kautta. Monesti lapsen tarpeet kattavat laajasti eri palvelujen ja siten eri asiantuntemuksen aloja. Auttamistyön ammattilaisilla ei siten ole tietoa eikä mahdollisuuttakaan puuttua lapsen muiden, toisten ammattilaisten vastuulle kuuluvien ongelmien selvittämiseen ja hoitamiseen. Vanhemmille puolestaan rakentuu arjen kulussa kokonaisvaltainen käsitys lapsensa terveydestä ja tarpeista sekä aikaisemmista hoidoista ja diagnooseista. Tämä vanhempien kokonaisvaltainen tieto voi täyttää kapea-alaisen erityisosaamisen ja vastuun hajautumisen synnyttämiä tiedollisia aukkoja. Vanhempien mahdollisesti useiden vuosien aikana kertynyt asiantuntemus lapsestaan ja hänen tilanteestaan on korvaamatonta myös siksi, että erityistarpeet ja erilaiset vammat tai oireyhtymät eivät koskaan yhdisty täysin samalla tavalla. Jokainen lapsi ja hänen tarpeensa ovat erilaisia, jolloin yleispäteviä 
hoitosuosituksia ei voi välttämättä noudattaa eikä hyviä käytäntöjä tai toimintamalleja ole käytettävissä.

Vanhempien asiantuntijuuden merkityksen tunnustaminen ja sen näkeminen välttämättömänä lapsen kokonaisvaltaisen tilanteen hahmottamiseksi poistaa myös vastakkainasettelua auttamistyön toimijoiden väliltä. Tämä edellyttää sekä arvoasetelmien tunnistamista että eri toimijoiden halukkuutta ja kykyä kyseenalaistaa totutut käytännöt. Tiedon kategorioihin liittyvien arvoasetelmien tunnistaminen tarjoaa mahdollisuuden päästä yli erilaisten tietoperustojen yhteismitattomuuden ja yhteensovittamisen ongelmasta ja kulttuurisesti rakentuvien arvoasetelmien epätasa-arvoa tuottavista käytännöistä (myös Koskinen 2014). Tämä mahdollistaa myös auttamistyön neuvottelujen kehittämisen siten, että erilaisille tietoperustoille annetaan oma paikkansa kokonaiskuvan hahmottamisessa ja lapsen tarpeiden ymmärtämisessä. Kun vanhempien kokemustiedon annetaan täydentää hoitotyön ammattilaisten tietoja, lapsen tilanne voidaan nähdä laaja-alaisesti ja arkielämän tarpeet huomioivasta näkökulmasta. Näin katsottuna myös vanhempien tietoperustalle on oma paikkansa kokonaisvaltaisen ymmärryksen luomisessa, johon auttamistyön neuvotteluissa pyritään.

\section{LÄHTEET}

\section{Tutkimusaineistot}

Aalto, Heinonen, Kantoluoto, Lehtomäki, Lähdemäki, Paganius \& Salonen (toim.) 2015: Leijonaemojen tarinat - Kasvu erityislapsen vanhemmaksi.. Helsinki: Leijonaemot ry.

Haastattelut 1-4. Toteutettu syksyllä 2015, haastattelijana Pilvi Hämeenaho. Aineistot kirjoittajan hallussa.

\section{Kirjallisuus}

Alasuutari, Maarit 2010: Suunniteltu lapsuus: keskustelut lapsen varhaiskasvatuksesta päivähoidossa. Tampere: Vastapaino.

Bowker, Geoffrey C. \& Susan Leigh Star 2000: Sorting things Out. Classification and its Consequences. Massachusetts: The MIT Press.

Buchert, Ulla 2015: Maahanmuuttajuuden institutionaaliset kategoriat. Helsinki: Kuntoutussäätiö.

Collins, Harry \& Robert Evans 2007: Rethinking expertise. Chicago: University of Chicago Press.

Dew, Kevin 2016: Purifying and hybridizing categories in healthcare decisionmaking: the clinic, the home and the multidisciplinary team meeting. - Health Sociology Review 25(2): 142-156.

Farrer, Linden, Claudia Marinetti, Yoline Kuipers Cavago \& Caroline Costongs 2015: Advocacy for Health Equity: A Synthesis Review. - The Milbank Quarterly 93(2): 392-437. 
Fischer, Pamela 2008: Wellbeing and empowerment: the importance of recognition. - Sociology of Health \& Illness 30(4): 583-598.

Frank, Arthur W. Corman, Michael K., Gish, Jessica A. \& Lawton, Paul 2010: HealerPatient Interaction: New Mediations in Clinical Relationships. - Ivy Bourgeault, Robert Dingwall \& Raymond de Vries (eds.), Qualitative Methods in Health Research. Lontoo: Sage. 34-52.

Goldstein, Diane 2000: 'When Ovaries Retire': Contrasting Women's Experiences with Feminist and Medical Models of Menopause. - Health 4(3): 309-323

Goldstein, Diane 2013: Vernacular Turns: Narrative, Local Knowledge, and the Changed Context of Folklore. - Journal of American Folklore 128(508): 125-145.

Hall, Stuart 1992: Cultural studies and its theoretical legacies. - Lawrence Grossberg, Cary Nelson \& Paula Treichler (eds.), Cultural Studies. New York: Routledge. 277-294.

Haraway, Donna 1993: The biopolitics of postmodern bodies: determinations of self in immune system discourse. - Shirley Lindembaum \& Margaret M. Lock (eds.), Knowledge, Power, and Practice. The Anthropology of Medicine and Everyday Life. Berkeley: University of California Press. 364-410.

Honkasalo, Marja-Liisa 2008a: Etnografia terveyden, sairauden ja terveydenhuollon tutkimuksessa. Sosiaalilääketieteellinen aikakauslehti 4: 4-17.

Honkasalo Marja-Liisa 2008b: Reikä sydämessä. Tampere: Vastapaino.

Hugman, Richard 2013: Culture, Values and Ethics in Social Work. New York: Routledge.

Hurtig, Johanna \& Merja Laitinen 2006: Paha ihmisyyden ja ammatillisen auttamisen haasteena. - Laitinen, Merja \& Johanna Hurtig (toim.), Pahan kosketus. Ihmisyyden ja auttamistyön varjojen jäljillä. Jyväskylä: PS-Kustannus. 8-17.

Hämeenaho, Pilvi 2014: Hyvinvoinnin verkostot maaseudulla asuvien äitien arjessa. Etnologinen tutkimus palvelujen käytöstä ja hyvän arjen rakentumisesta. Helsinki: Terveyden ja hyvinvoinnin laitos.

Itäpuisto, Maritta 2005: Kokemuksia alkoholiongelmaisten vanhempien kanssa eletystä lapsuudesta. Kuopio: Kuopion yliopisto.

Jokinen, Arja 2012: Kategoriat, instituutiot ja sosiaalisen järjestyksen tuottaminen. - Jokinen, Arja, Kirsi Juhila \& Eero Suoninen (toim.), Kategoriat, kulttuuri ja moraali. Tampere: Vastapaino. 227-266.

Juhila, Kirsi 2012: Poikkeavan kategorian jäsenyyden tuottaminen ja vastustaminen. - Jokinen, Arja, Kirsi Juhila \& Eero Suoninen (toim.), Kategoriat, kulttuuri ja moraali, Tampere: Vastapaino. 175-225.

Kangas, Ilka 2003: Sairaan asiantuntijuus - tieto ja kokemus sairastamisen arjessa. - Honkasalo, Marja-Liisa, Ilka Kangas, \& Ullamaija Seppälä (toim.), Sairas, potilas, omainen. Näkökulmia sairauden kokemukseen. Helsinki: Suomalaisen Kirjallisuuden Seura, 73-95.

Kelly, Susan K. 2010: Qualitative Interviewing Techniques and Styles. - Bourgeault, Ivy, Robert Dingwall \& Raymond de Vries (eds.), Qualitative Methods in Health Research. Lontoo: Sage. 305-326.

Koivikko, Matti \& Salla Sipari 2006. Lapsen ja nuoren hyvä kuntoutus. Helsinki: Vajaaliikkeisten Kunto ry. 
Koskinen, Inkeri 2014: Alkuperäiskansojen tieto tutkimuksessa: tieteenfilosofinen näkökulma. - Hämeenaho, Pilvi \& Eerika Koskinen-Koivisto (toim.), Moniulotteinen etnografia. Helsinki: Ethnos ry. 128-152.

Laurén, Kirsi 2010: Kirjoitetun kokemuksen kiehtovuus.- Pöysä, Jyrki, Helmi Järviluoma \& Sinikka Vakimo (toim.), Vaeltavat metodit. Joensuu: Kultaneito. 426-449.

Lock, Margaret 2001: The Tempering of Medical Anthropology: Troubling Natural Categories. - Medical Anthropology Quarterly 15(4): 478-492.

Lonka, Kirsi 2015: Leijonaemojen matkassa. Teoksessa Leijonaemojen tarinat, 9-14. Helsinki: Leijonaemot ry.

Losake, Donilee 2007: Thinking about social problems. An Introduction to social construction perspectives. New Brunswick: Transaction.

Mertala, Sirpa 2011: Yhdessä tietämisen episodeja. Terveydenhuollon kompleksiset työympäristöt. Rovaniemi: Lapin yliopistokustannus.

Miller, Peter \& Nikolas Rose 2010: Miten meitä hallitaan. Tampere: Vastapaino.

Nussbaum, Martha C. 2011: Creating Capabilities. The Human Development Approach. Lontoo: The Belknap Press of Harvard University Press.

O'Dell, Tom \& Robert Willim 2016: Kulttuurianalyysin ja etnologisen koulutuksen tavoitteiden uudelleenmäärittely. Kuinka tavoittaa uusia yleisöjä yliopiston ulkopuolella? - Jouhki, Jukka \& Tytti Steel (toim.), Etnologinen tulkinta ja analyysi. Kohti avoimempaa tutkimusprosessia, Helsinki: Ethnos ry. 41-80.

Ortner, Sherry 1984: Theory of Anthropology since the Sixties. - Comparative Studies in Society and History 126(1): 126-66.

Paal, Piret 2011: Kun sairastuin syöpään. Kirjoitettujen kertomusten funktiosta ja statuksesta. - Lakomäki, Sami, Pauliina Latvala \& Kirsi Laurén (toim.), Tekstien rajoilla. Monitieteisiä näkökulmia kirjoitettuihin aineistoihin. Helsinki: Suomalaisen Kirjallisuuden Seura. 158-177.

Perlin, Michael 2011: International Human Rights and Mental Disability Law: When the Silenced are Heard. Oxford: Oxford University Press.

Pfeiffer, Steven I. \& Leigh Cundari 1999: Inclusion Practices with Special Needs Students: Theory, Research, and Application. New York: Routledge.

Pinder, Ruth 2010: The Dilemmas of Advocacy: the Paradox of Giving in Disability Research. - Bourgeault, Ivy, Robert Dingwall \& Raymond de Vries (eds.), Qualitative Methods in Health Research. Lontoo: Sage. 714-729.

Pohjola, Anneli 2006: Pahan säikeitä auttamistyössä. - Laitinen, Merja \& Johanna Hurtig (toim.), Pahan kosketus. Ihmisyyden ja auttamistyön varjojen jäljillä. Jyväskylä: PS-Kustannus. 42-62.

Popay, Jennifer \& Gareth Williams 1996: Public health research and lay knowledge. - Social Science and Medicine 42(5): 759-768.

Prior, Lindsay 2003: Belief, knowledge and expertise: the emergence of the lay expert in medical sociology. - Sociology of Health \& IIlness 25: 41-57.

Riessman, Catherine Kohler 1993: Narrative Analysis. Newbury Park: Sage.

Seppälä, Eeva \& Arja Veijola 2012: Lapsen ja nuoren kuntoutuksen kehittäminen. Helsinki: Vajaaliikkeisten Kunto ry. 
Strauss, Anselm 1978: Negotiations. Varieties, Contexts, Processes, and Social Order. San Francisco: Jossey-Bass.

Suopajärvi, Tiina 2009: Sukupuoli meni metsään. Luonnon ja sukupuolen polkuja metsäammattilaisuudessa. Helsinki: Suomalaisen Kirjallisuuden Seura.

Toom, Auli 2008: Hiljaista tietoa vai tietämistä? Näkökulmia hiljaisen tiedon käsitteen tarkasteluun. - Toom, Auli, Jussi Onnismaa \& Anneli Kajanto (toim.), Hiljainen tieto - tietämistä, toimimista, taitavuutta. Helsinki: Kansanvalistusseura. 33-58.

Tuomaala, Salome 2008: Naisten kokemuskertomukset kriittisenä tietona abortista. - Sosiaalilääketieteellinen aikakauslehti 45, 48-58.

Venkatapuram, Sridhar 2011: Health Justice. Cambridge: Polity Press.

Williams, Gareth \& Eva Elliot 2010: Exploring Social Inequalities in Health: the Importance of Thinking Qualitatively. - Bourgeault, Ivy, Robert Dingwall \& Raymond de Vries (eds.), Qualitative Methods in Health Research. Lontoo: Sage. 106-122.

Filosofian tohtori, etnologi Pilvi Hämeenaho työskentelee Suomen Akatemian tutkijatohtorina Jyväskylän yliopiston historian ja etnologian laitoksella. 